\title{
Characterisation of pvmdr1 and pvdhfr genes associated with chemoresistance in Brazilian Plasmodium vivax isolates
}

\author{
Bianca Ervatti Gama', Natália Ketrin Almeida de Oliveira', José Maria de Souza², Cláudio Tadeu \\ Daniel-Ribeiro', Maria de Fátima Ferreira-da-Cruz ${ }^{1 /+}$
}

'Laboratório de Pesquisas em Malária, CPD-Mal, Instituto Oswaldo Cruz-Fiocruz, Avenida Brasil 4365, 21040-360 Rio de Janeiro, RJ, Brasil

${ }^{2}$ Ambulatório e Laboratório de Ensaios Clínicos em Malária, Secretaria de Vigilância Sanitária, Instituto Evandro Chagas, Belém, PA, Brasil

Plasmodium vivax control is now being hampered by drug resistance. Orthologous Plasmodium falciparum genes linked to chloroquine or sulfadoxine-pyrimethamine chemoresistance have been identified in P. vivax parasites, but few studies have been performed. The goal of the present work is to characterise pvmdrl and pvdhfr genes in parasite isolates from a Brazilian endemic area where no molecular investigation had been previously conducted. The pvmdrl analysis revealed the existence of single (85.7\%) and double (14.3\%) mutant haplotypes, while the pvdhfr examination showed the presence of double (57.2\%) and triple (42.8\%) mutant haplotypes. The implications of these findings are discussed.

Key words: Plasmodium vivax - malaria - chemoresistance - pvmdr1 - pvdhfr

Although Plasmodium vivax has long been neglected, it is the most ubiquitous human malaria parasite, causing up to $50 \%$ of malaria cases outside Africa (Mendis et al. 2001). In effect, more than 2.5 billion inhabitants of the Middle East, Asia, Eastern and South Africa, Central and South America and Oceania are exposed to $P$. vivax infection, leading to 71-391 million cases of malaria vivax per year (Guerra et al. 2006, Price et al. 2007). In Brazil, this parasite is responsible for around $85 \%$ of cases (MS 2008). Control measures include prompt diagnosis followed by adequate treatment with chloroquine (CQ), a blood schizonticide that remains the first-line treatment in most of the world; thus, the emergence of CQ P. vivax chemoresistance represents a hurdle to malaria control.

The first case of $P$. vivax resistance to CQ was described in 1989 in Papua New Guinea (Rieckmann et al. 1989). Since then periodic reports have been made in Oceanian and in Asian and South American countries (Baird 2004, Lee et al. 2009), including Brazil (Alecrim et al. 1999, de Santana Filho et al. 2007). In contrast to P. falciparum parasites, effective in vitro culture systems for $P$. vivax parasites are not available, a fact that makes the biological identification of CQ resistance of $P$. vivax parasites difficult. In addition, clinical recognition of CQ-resistant $P$. vivax parasites can be confusing in endemic areas in view of the difficulties in distinguishing between recrudescence due to true treatment failure, relapse from the hypnozoite stage and new infection. Thus, a database of the mutations possibly associated with in vivo drug resistance could help

Financial support: $\mathrm{POM} / \mathrm{PEF} / \mathrm{IOC} /$ Fiocruz, PAPES/Fiocruz/CNPq, FAPERJ, CAPES

+ Corresponding author: mffcruz@ioc.fiocruz.br

Received 2 July 2009

Accepted 7 October 2009 our understanding of the molecular mechanisms underlying CQ resistance in $P$. vivax infections.

Orthologous $P$. falciparum genes linked to $\mathrm{CQ}$ chemoresistance, such as $p v m d r 1$, have also been identified in P. vivax parasites (Brega et al. 2005). However, few studies concerning these genes were conducted so far (Nomura et al. 2001, Brega et al. 2005, Sá et al. 2005, Suwanarusk et al. 2007, 2008, Barnadas et al. 2008a, Imwong et al. 2008, Marfurt et al. 2008, FernandezBecerra et al. 2009, Orjuela-Sánchez et al. 2009).

Another orthologous $P$. falciparum gene, in this case associated with pyrimethamine and, by extension, with sulfadoxine-pyrimethamine (SP) chemoresistance, was also identified in P. vivax (De Pécoulas et al. 1998a). Molecular, clinical and epidemiological studies have also shown that, as for $P$. falciparum parasites, resistance is a consequence of cumulative point mutations in the $p v d h f r$ gene (De Pécoulas et al. 1998b).

Nowadays, neither $P$. vivax nor $P$. falciparum malaria cases are treated with SP in Brazil. However, in view of the increasing prevalence of $P$. falciparum $\mathrm{CQ}$ resistance, SP was largely employed in Brazil during the 70 's and 80's to replace CQ in falciparum malaria treatment. Therefore, considering that co-infections of $P$. falciparum and $P$. vivax parasites were common in Brazil and that such co-infections could be misdiagnosed or even undiagnosed, $P$. vivax parasites must have been often exposed to this drug combination and the selection of SP-resistant $P$. vivax parasites might have occurred.

The goal of the present study was to characterise pvmdrl and pvdhfr gene single nucleotide polymorphisms (SNPs) in P. vivax patients, living in Paragominas, state of Pará, where no molecular investigation of these genes has been previously conducted.

\section{PATIENTS, MATERIAL AND METHODS}

Study site, blood samples and DNA extraction - P. vivax parasites were genotyped in an initial set of 28 blood samples collected in 2004 at the time of diagnosis. 
The inclusion criterion comprised monoinfected P.vivax patients with uncomplicated malaria. Patients who were pregnant as well as individuals less than 18 years of age and indigenous populations were excluded from the study. After obtaining informed consent, venous blood collection was performed according to protocols previously approved by the Ethical Research Committees of Fiocruz and of local study sites. DNA was extracted from $1 \mathrm{~mL}$ of cryopreserved blood using QIAamp midi columns, as described by the manufacturer (Qiagen).

Polymerase chain reaction (PCR) and electrophoresis - Two single PCR techniques were employed to amplify a partial DNA sequence containing some SNPs for target genes including: SNPs Y976F and F1076L for pvmdrl and SNPs F57L/I, S58R, T61M, S117T/N and I173F/L for $p v d h f r$. The protocols for $p v m d r 1$ and $p v d-$ $h f r$ PCRs have been described elsewhere (Brega et al. 2004, 2005). PCR products were analysed by ethidium bromide-stained agarose-gel (2\%) electrophoresis.

DNA sequencing - After purification using the Wizard SV Gel and PCR Clean-Up System (Promega), the amplified fragments were sequenced using Big Dye ${ }^{\circledR}$ Terminator Cycle Sequencing Ready Reaction version 3.1 (Applied Biosystems) and ABI PRISM DNA Analyzer 3730 (Applied Biosystems) from the Genomic Platform/PDTIS/Fiocruz (Otto et al. 2008).

\section{RESULTS AND DISCUSSION}

All 28 samples were successfully amplified and the corresponding DNA was sequenced. For SNPs Y976F and $F 1076 \mathrm{~L}$, the $p v m d r 1$ analysis revealed the existence of two haplotypes: FF, or single-mutant (85.7\%) and FL, or double-mutant (14.3\%). Additionally, two other novel polymorphisms were noted in one single sample, comprising a synonymous mutation at codon 1022 (CTA to TTA, both coding for leucine) and a non-synonymous change at codon 1070, from phenylalanine to leucine. None of the recently reported SNPs from $P$. vivax parasites from another Brazilian endemic area (Manaus, Amazonia) were found in our study (Orjuela-Sánchez et al. 2009); in contrast, all of our samples presented the Y976F mutation - one of the early chemoresistance molecular marker candidates.

Surprisingly, no wild-type haplotype (YF that corresponds to CQ sensitivity) was found. This strikingly contrasts to the only $10 \%$ of CQ in vivo therapeutic failures recently reported in Brazil (De Santana Filho et al. 2007). This finding might suggest that the Y976F pvm$d r l$ point mutation, i.e., the SNP associated with CQ resistance (Brega et al. 2005, Suwanarusk et al. 2007), was not valuable for monitoring CQ resistance in Brazil. The same phenomenon may be occurring in Madagascar, where this codon was mutated at a high frequency, in spite of a low prevalence of in vivo $P$. vivax CQ-resistant parasites (Barnadas et al. 2008a). In addition, the Y976F mutation was not found in isolates from three patients with recrudescent disease, a recently finding that reinforced our proposition (Orjuela-Sánchez et al. 2009).

The pvdhfr analysis also revealed the existence of two haplotypes, considering SNPs F57L/I, S58R, T61M,
S117T/N and I173F/L. FRTNI or double-mutant (S58R $+\mathrm{S} 117 \mathrm{~N}$ ) were found in $57.2 \%$ of the samples; FRTNL or triple-mutant (S58R + S117N + I173L) were found in $42.8 \%$ of the samples. No wild-type haplotype FSTSI was found, as expected, and two samples presented an atypical exchange at codon 116, from serine to glycine, that was newly identified in French Guiana samples (Barnadas et al. 2009).

The double $p v d h f r$ mutant haplotype has already been described in samples from Indonesia (Hastings et al. 2004), Thailand (Brega et al. 2004), Ethiopia (Schunk et al. 2006), China, East Timor, Philipines, Vanuatu, Vietnam (Auliff et al. 2006), Papua New Guinea (Marfurt et al. 2008), Madagascar (Barnadas et al. 2008b) and Iran (Zakeri et al. 2009). The same double and triple $p v d h f r$ mutants were also found in $P$. vivax parasites from French Guiana (Brega et al. 2004, Barnadas et al. 2009), the only locality where the I173L SNP was identified before the present work. Therefore, the genetic similarity of haplotypes and this specific SNP recorded in $P$. vivax parasites from two neighbouring South-American countries could reflect the existence of a geographic subdivision of different $P$. vivax parasites in samples from the old and new worlds ( $\mathrm{Li}$ et al. 2001, Brega et al. 2004). Although when other authors looked at the population genetics of the parasites using microsatellites, they did not find a significant differentiation between parasites from the same continent or even within the same country (Karunaweera et al. 2008).

Considering that, besides underlying immunity conditions and other host factors, in vivo $P$. vivax pyrimethamine resistance is associated with the presence of multiple mutations in the $p v d h f r$ gene, we conclude that studies, such as the one reported here, can provide critical information on the potential emergence of SP resistance in endemic areas, if the increase of CQ treatment failure persuades health care policy programs to shift from CQ to this antifolate drug treatment. These findings will be further complemented by an additional analysis concerning the $p v d h p s$ gene, the orthologous gene to falciparum pfdhps, which mediates resistance to sulfadoxine, the counterpart of pyrimethamine in the SP combination.

Finally, since the molecular mechanisms of $P$. vivax CQ resistance remain elusive, more studies must be carried out on the prevalence of chemoresistance molecular markers as well as on the in vivo and in vitro sensitivity of antimalarial drugs to validate CQ molecular markers for screening and monitoring $P$. vivax CQ-resistant parasites.

\section{ACKNOWLEDGMENTS}

To Paulo Renato Rivas Totino and Evelyn Kety Pratt Riccio, that kindly provided blood samples for this study, and to the staff from the Genomic Platform/PDTIS/Fiocruz.

\section{REFERENCES}

Alecrim MG, Alecrim W, Macêdo V 1999. Plasmodium vivax resistance to chloroquine (R2) and mefloquine (R3) in Brazilian Amazon Region. Rev Soc Bras Med Trop 32: 67-68.

Auliff A, Wilson DW, Russell B, Gao Q, Chen N, Anh le N, Maguire J, Bell D, O’Neil MT, Cheng Q 2006. Amino acid mutations in 
Plasmodium vivax DHFR and DHPS from several geographical regions and susceptibility to antifolate drugs. Am J Trop Med Hyg 75: 617-621.

Baird JK 2004. Chloroquine resistance in Plasmodium vivax. Antimicrob Agents Chemother 48: 4075-4083.

Barnadas C, Musset L, Legrand E, Tichit M, Briolant S, Fusai T, Rogier C, Bouchier C, Picot S, Ménard D 2009. High prevalence and fixation of Plasmodium vivax dhfr/dhps mutations related to sulfadoxine/pyrimethamine resistance in French Guiana. Am $J$ Trop Med Hyg 81: 19-22.

Barnadas C, Ratsimbasoa A, Tichit M, Bouchier C, Jahevitra M, Picot S, Ménard D 2008a. Plasmodium vivax resistance to chloroquine in Madagascar: clinical efficacy and polymorphisms in $p v m d r 1$ and pvcrt-o genes. Antimicrob Agents Chemother 52: 4233-4240.

Barnadas C, Tichit M, Bouchier C, Ratsimbasoa A, Randrianasolo L, Raherinjafy R, Jahevitra M, Picot S, Ménard D 2008b. Plasmodium vivax dhfr and dhps mutations in isolates from Madagascar and therapeutic response to sulphadoxine-pyrimethamine. Malar $J$ 7: 35.

Brega S, de Monbrison F, Severini C, Udomsangpetch R, Sutanto I, Ruckert P, Peyron F, Picot S 2004. Real-time PCR for dihydrofolate reductase gene single-nucleotide polymorphisms in Plasmodium vivax isolates. Antimicrob Agents Chemother 48: 2581-2587.

Brega S, Meslin B, de Monbrison F, Severini C, Gradoni L, Udomsangpetch R, Sutanto I, Peyron F, Picot S 2005. Identification of the Plasmodium vivax $m d r$-like gene ( $p v m d r l$ ) and analysis of single-nucleotide polymorphisms among isolates from different areas of endemicity. J Infect Dis 191: 272-277.

De Pécoulas PE, Basco LK, Tahar R, Ouatas T, Mazabraud A 1998a. Analysis of the Plasmodium vivax dihydrofolate reductase-thymidylate synthase gene sequence. Gene 211: 177-185.

De Pécoulas PE, Tahar R, Ouatas T, Mazabraud A, Basco LK 1998b. Sequence variations in the Plasmodium vivax dihydrofolate reductase-thymidylate synthase gene and their relationship with pyrimethamine resistance. Mol Biochem Parasitol 92: 265-273.

De Santana Filho FS, Arcanjo AR, Cheuan YM, Costa MR, Martinez-Espinosa FE, Vieira JL, Barbosa MG, Alecrim WD, Alecrim MG 2007. Chloroquine-resistant Plasmodium vivax, Brazilian Amazon. Emerg Infect Dis 13: 1125-1126.

Fernandez-Becerra C, Pinazo MJ, González A, Alonso PL, del Portillo HA, Gascón J 2009. Increased expression levels of the pvcrt-o and pvmdrl genes in a patient with severe Plasmodium vivax malaria. Malar J 8: 55.

Guerra CA, Snow RW, Hay SI 2006. Mapping the global extent of malaria in 2005. Trends Parasitol 22: 353-358.

Hastings MD, Porter KM, Maguire JD, Susanti I, Kania W, Bangs MJ, Sibley CH, Baird JK 2004. Dihydrofolate reductase mutations in Plasmodium vivax from Indonesia and therapeutic response to sulfadoxine plus pyrimethamine. J Infect Dis 189: 744-750.

Imwong M, Pukrittayakamee S, Pongtavornpinyo W, Nakeesathit S, Nair S, Newton P, Nosten F, Anderson TJ, Dondorp A, Day NP, White NJ 2008. Gene amplification of the multidrug resistance 1 gene of Plasmodium vivax isolates from Thailand, Laos, and Myanmar. Antimicrob Agents Chemother 52: 2657-2659.

Karunaweera ND, Ferreira MU, Munasinghe A, Barnwell JW, Collins WE, King CL, Kawamoto F, Hartl DL, Wirth DF 2008. Extensive microsatellite diversity in the human malaria parasite Plasmodium vivax. Gene 410: 105-112.

Lee KS, Kim TH, Kim ES, Lim HS, Yeom JS, Jun G, Park JW 2009.
Chloroquine-resistant Plasmodium vivax in the Republic of Korea. Am J Trop Med Hyg 80: 215-217.

Li J, Collins WE, Wirtz RA, Rathore D, Lal A, McCutchan TF 2001. Geographic subdivision of the range of the malaria parasite Plasmodium vivax. Emerg Infect Dis 7: 35-42.

Marfurt J, de Monbrison F, Brega S, Barbollat L, Müller I, Sie A, Goroti M, Reeder JC, Beck HP, Picot S, Genton B 2008. Molecular markers of in vivo Plasmodium vivax resistance to amodiaquine plus sulfadoxine-pyrimethamine: mutations in $p v d h f r$ and pvmdr1. J Infect Dis 198: 409-417.

Mendis K, Sina BJ, Marchesini P, Carter R 2001. The neglected burden of Plasmodium vivax malaria. Am J Trop Med Hyg 64: 97-106.

MS - Ministério da Saúde 2008. Secretaria de Vigilância em Saúde [homepage on the internet]. Situação epidemiológica da malária no Brasil 2008 [cited 2009 July 08]. Available from: http://portal. saude.gov.br/portal/arquivos/pdf/folder_malaria_2008_final.pdf.

Nomura T, Carlton JM, Baird JK, del Portillo HA, Fryauff DJ, Rathore D, Fidock DA, Su X, Collins WE, McCutchan TF, Wootton JC, Wellems TE 2001. Evidence for different mechanisms of chloroquine resistance in 2 Plasmodium species that cause human malaria. J Infect Dis 183: 1653-1661.

Orjuela-Sánchez P, de Santana Filho FS, Machado-Lima A, Chehuan YF, Costa MR, Alecrim MG, del Portillo HA 2009. Analysis of single-nucleotide polymorphisms in the $c r t-o$ and $m d r l$ genes of Plasmodium vivax among chloroquine-resistant isolates from the Brazilian Amazon Region. Antimicrob Agents Chemother 53: 3561-3564.

Otto TD, Vasconcellos EA, Gomes LHF, Moreira AS, Degrave WM, Mendonça-Lima L, Alves-Ferreira M 2008. ChromaPipe: a pipeline for analysis, quality control and management for a DNA sequencing facility. Genet Mol Res 7: 861-871.

Price RN, Tjitra E, Guerra CA, Yeung S, White NJ, Anstey NM 2007. Vivax malaria: neglected and not benign. Am J Trop Med Hyg 77: 79-87.

Rieckmann KH, Davis DR, Hutton DC 1989. Plasmodium vivax resistance to chloroquine? Lancet 2: 1183-1184.

Sá JM, Nomura T, Neves J, Baird JK, Wellems TE, del Portillo HA 2005. Plasmodium vivax: allele variants of the $m d r l$ gene do not associate with chloroquine resistance among isolates from Brazil, Papua, and monkey-adapted strains. Exp Parasitol 109: 256-259.

Schunk M, Kumma WP, Miranda IB, Osman ME, Roewer S, Alano A, Löscher T, Bienzle U, Mockenhaupt FP 2006. High prevalence of drug-resistance mutations in Plasmodium falciparum and Plasmodium vivax in Southern Ethiopia. Malar J 5: 54.

Suwanarusk R, Chavchich M, Russell B, Jaidee A, Chalfein F, Barends M, Prasetyorini B, Kenangalem E, Piera KA, Lek-Uthai U, Anstey NM, Tjitra E, Nosten F, Cheng Q, Price RN 2008. Amplification of pvmdrl associated with multidrug-resistant Plasmodium vivax. J Infect Dis 198: 1558-1564.

Suwanarusk R, Russell B, Chavchich M, Chalfein F, Kenangalem E, Kosaisavee V, Prasetyorini B, Piera KA, Barends M, Brockman A, Lek-Uthai U, Anstey NM, Tjitra E, Nosten F, Cheng Q, Price RN 2007. Chloroquine resistant Plasmodium vivax: in vitro characterization and association with molecular polymorphisms. PLOS ONE 2: 1-9.

Zakeri S, Motmaen SR, Afsharpad M, Djadid ND 2009. Molecular characterization of antifolates resistance-associated genes ( $d h f r$ and dhps) in Plasmodium vivax isolates from the Middle East. Malar J 8: 20. 